\section{Growth Response of Container-grown Pin Oak and Japanese Maple Seedlings to Sulfur Fertilization}

\author{
Jake F. Browder, ${ }^{1}$ Alexander X. Niemiera, ${ }^{2}$ J. Roger Harris, ${ }^{2}$ and \\ Robert D. Wright ${ }^{3}$ \\ Department of Horticulture, Virginia Polytechnic Institute and State University, \\ Blacksburg, VA 24061
}

Additional index words. Acer palmatum, Micromax, pine bark, Quercus palustris, soilless

\begin{abstract}
Sulfur (S) is essential to the growth of higher plants; however, research on $\mathrm{S}$ fertilizer requirements for container-grown nursery tree species has not been established. The purpose of this study was to determine the substrate solution $\mathrm{S}$ concentration that maximizes the growth of container-grown pin oak (Quercus palustris Münchh) (pin oak$\mathrm{K}_{2} \mathrm{SO}_{4}$ experiment) and japanese maple (Acer palmatum Thunb.) (japanese maple- $\mathrm{K}_{2} \mathrm{SO}_{4}$ experiment) in a pine bark (PB) substrate. Both species were fertilized with solutions supplying a range of $S$ concentrations $\left(0,1,2,5,10,20,40\right.$, or $\left.80 \mathrm{mg} \cdot \mathrm{L}^{-1}\right)$ using $\mathrm{K}_{2} \mathrm{SO}_{4}$. Regression analysis revealed that dry weights of both species were near maximum at the predicted application concentration of $30 \mathrm{mg} \cdot \mathrm{L}^{-1} \mathrm{~S}$, which corresponded to about 15 and $7 \mathrm{mg} \cdot \mathrm{L}^{-1} \mathrm{~S}$ in substrate solution for pin oak and japanese maple, respectively. In a Micromax, $\mathrm{FeSO}_{4}$, lime experiment, $\mathrm{S}$ was supplied to pin oak via a preplant micronutrient sulfate fertilizer or $\mathrm{FeSO}_{4}$ in limed or unlimed $\mathrm{PB}$. When the $\mathrm{PB}$ pH was relatively low (4.5, unlimed), $\mathrm{FeSO}_{4}$ and the preplant micronutrient fertilizer were effective in supplying ample S. However, when the PB pH was relatively high (6.1, limed), the preplant micronutrient fertilizer with micronutrients in a sulfate form was more effective in supplying $\mathrm{S}$ and micronutrients than $\mathrm{FeSO}_{4}$.
\end{abstract}

Sulfur is essential to the growth of higher plants since it is a major component of the amino acids cysteine and methionine, which are precursors to proteins (Leustek et al., 2000; Mengel and Kirkby, 2001). Additionally, S is a contributing factor in the regulation of plant photosynthesis and water relations (Kastori et al., 2000). Less attention is given to $S$ as a fertilizer additive since it is supplied via atmospheric contaminants, and weathering of soil organic compounds. However, according to the National Atmospheric Deposition Program (NADP) (2004), sulfate deposition in the Eastern United States has decreased by about $50 \%$ over the past two decades as a result of the Clean Air Act. If this trend continues, plant $\mathrm{S}$ deficiency symptoms may be common if fertilizers do not adequately supply S.

Sulfur deficiency symptoms include chlorosis and necrosis of the youngest leaves (Dale et al., 1990; Hu et al., 1991; Nelson, 1996), reduction in chlorophyll content (Bixby and Beaton, 1970), reduced stomatal conductance, transpiration, and photosynthesis (Karmoker et al., 1991), as well as overall reduced growth (Dale et al., 1990; Macz et al., 2001; Finch et al., 1997). Several studies have shown a

Received for publication 16 Dec. 2004. Accepted for publication $15 \mathrm{Feb} .2005$. This paper is a portion of a thesis submitted by J.F. Browder. Appreciation is extended to Velva Groover, John James, Scott Rapier, Maura Wood, and Joyce Shelton for valuable assistance. Use of trade names does not imply endorsement of products named to the exclusion of other products that may also be suitable.

${ }^{1}$ Graduate student.

${ }^{2}$ Associate professor.

${ }^{3}$ Professor. need for $\mathrm{S}$ fertilization to maximize plant growth. For example, peach (Prunus persica L. Batsch) grown in sand culture required 4 $\mathrm{mg} \cdot \mathrm{L}^{-1} \mathrm{~S}$ (Finch et al., 1997); sugar beet (Beta vulgaris $\mathrm{L}$.) grown in solution culture required $32 \mathrm{mg} \cdot \mathrm{L}^{-1} \mathrm{~S}$ (Kastori et al., 2000); chrysanthemum (Dendranthema grandiflora Tzvelev.) required $8 \mathrm{mg} \cdot \mathrm{L}^{-1} \mathrm{~S}$ (Huang et al., 1997) in solution culture and $10 \mathrm{mg} \cdot \mathrm{L}^{-1} \mathrm{~S}$ (Macz et al., 2001) when container-grown in a peat-based substrate; and finally, container-grown stock (Mathiola incana L. 'Austral') and cabbage (Brassica oleracea L. 'Lion Heart') in a pine bark (PB) substrate required 25 and $27 \mathrm{mg} \cdot \mathrm{L}^{-1}$ S, respectively (Handreck, 1986). In general, Nelson (1996) stated "that most greenhouse crops require at least $16 \mathrm{mg} \cdot \mathrm{L}^{-1} \mathrm{~S}$ or greater in irrigation water."

Research documenting S fertilizer requirements for container-grown woody landscape plants such as trees and shrubs is scarce. Growers of container-grown woody plants commonly preplant amend their soilless substrates with commercial micronutrient fertilizers that contain S. In many of these fertilizers sulfate is the companion anion to the micronutrient cations such as $\mathrm{Fe}, \mathrm{Cu}, \mathrm{Mn}$, and $\mathrm{Zn}$. Browder (2004) observed that the growth response of pin oak (Quercus palustris Münchh) grown in $\mathrm{PB}$ amended with sulfated micronutrients was primarily due to the $\mathrm{S}$ component of the fertilizer. However, there is very little information on the substrate solution S concentration that maximizes the growth of container-grown woody plants. Therefore, the purpose of this study was to determine the substrate solution $\mathrm{S}$ concentration that maximizes the growth of container-grown pin oak and japanese maple in a PB substrate. Since there are several options for growers to supply Fe in addition to $\mathrm{S}$, some relatively inexpensive $\left(\mathrm{FeSO}_{4}\right)$ and some relatively expensive (preplant micronutrient fertilizer), two of these application options were investigated. In addition, since soilless substrates are commonly preplant amended with lime and lime reduces micronutrient availability, a lime treatment with the $\mathrm{S}$ application options was included.

\section{Materials and Methods}

Pin oak- $\mathrm{K}_{2} \mathrm{SO}_{4}$ experiment. In February 2004, stratified pin oak (Quercus palustris Münchh) (Sheffield's Seed Co., Inc., Locke, N.Y.) seeds were sown (3 $\mathrm{cm}$ deep) in flats of unamended PB. Seeds germinated in two weeks, and on 14 Feb. 2004 three uniform seedlings (about $2.5 \mathrm{~cm}$ tall) were transplanted into each 3.8-L (\#1) plastic container filled with milled PB (Pinus taeda L.). Treatments, which commenced on 25 Feb. 2004, were post-plant $\mathrm{S}$ application concentrations of $0,1,2,5,10$, 20,40 , or $80 \mathrm{mg} \cdot \mathrm{L}^{-1} \mathrm{~S}$ supplied by $\mathrm{K}_{2} \mathrm{SO}_{4}$. At each fertilization, each container received (beaker-applied) $250 \mathrm{~mL}$ of a solution with 300 $\mathrm{mg} \cdot \mathrm{L}^{-1} \mathrm{~N}\left(\mathrm{NH}_{4} \mathrm{NO}_{3}\right), 45 \mathrm{mg} \cdot \mathrm{L}^{-1} \mathrm{P}\left(\mathrm{H}_{3} \mathrm{PO}_{4}\right)$, and a combination of $\mathrm{K}_{2} \mathrm{SO}_{4}$ and $\mathrm{KCl}$ to provide $242 \mathrm{mg} \cdot \mathrm{L}^{-1} \mathrm{~K}$ and the aforementioned $\mathrm{S}$ rates. Irrigation frequency was based on plant need for water by lifting containers and assessing container weight. Seedlings were fertilized as needed to maintain a substrate solution electrical conductivity (EC) of 1.0 to $1.5 \mathrm{dS} \cdot \mathrm{m}^{-1}$. Pine bark solutions were extracted about every $7 \mathrm{~d}$ from containers using the pour-through (PT) method (Yeager et al., 1983) and analyzed for $\mathrm{pH}$ and $\mathrm{EC}$ to gauge the frequency of fertilizer reapplication. Alkalinity, $\mathrm{Ca}$, and $\mathrm{Mg}$ concentrations of irrigation water were $36,10.2$, and $4.2 \mathrm{mg} \cdot \mathrm{L}^{-1}$, respectively. Calcium and $\mathrm{Mg}$ supply (PT extractions) from $\mathrm{PB}$ and irrigation water (same PB lot used in this study) were 42 and $39 \mathrm{mg} \cdot \mathrm{L}^{-1}$, respectively (data not shown). Irrigation water micronutrient concentrations $\left(\mathrm{mg} \cdot \mathrm{L}^{-1}\right)$ were $0 \mathrm{Fe}, 0 \mathrm{Mn}, 0.04 \mathrm{Zn}$, and 0.002 $\mathrm{Cu}$. Pine bark solutions were extracted via PT on 24 Mar. 2004, and analyzed for S nutrient concentrations (determined by inductively coupled plasma (ICP) analysis). Plants were grown on raised benches in the Virginia Tech Greenhouse Facility (Blacksburg, Va.) having an average daytime temperature of $24^{\circ} \mathrm{C}$ and nighttime temperature of $21^{\circ} \mathrm{C}$. On 10 May 2004 , plant shoots were severed at the soil surface, dried for about $3 \mathrm{~d}$ at $65^{\circ} \mathrm{C}$, and dry weights were recorded. On 27 May 2004, dried shoot tissue was ground in a Cyclone Sample Mill (UD Corp., Boulder, Colo.) and analyzed for $\mathrm{S}, \mathrm{Cu}, \mathrm{Fe}, \mathrm{Mn}$, and $\mathrm{Zn}$, concentrations by ICP spectrometry (A \& L Eastern Agricultural Laboratories, Richmond, Va.).

Japanese maple- $\mathrm{K}_{2} \mathrm{SO}_{4}$ experiment. An experiment similar to the previous experiment was conducted from 24 Mar. to 17 May 2004 using japanese maple (Acer palmatum Thunb.). Pine bark solutions were extracted via PT on 17 May 2004 and analyzed as described above for $\mathrm{S}$.

A Micromax- $\mathrm{FeSO}_{4}$, lime experiment was 
conducted using two commercially available $\mathrm{S}$ sources, $\mathrm{FeSO}_{4} \cdot 7 \mathrm{H}_{2} \mathrm{O}$ and Micromax (MM) [O.M. Scott, Marysville, Ohio; $12 \% \mathrm{~S}, 0.1 \% \mathrm{~B}$ $\left(\mathrm{Na}_{2} \mathrm{~B}_{4} \mathrm{O}_{7}\right), 0.5 \% \mathrm{Cu}\left(\mathrm{CuSO}_{4}\right), 12 \% \mathrm{Fe}\left(\mathrm{FeSO}_{4}\right)$, $2.5 \% \mathrm{Mn}\left(\mathrm{MnSO}_{4}\right), 0.05 \% \mathrm{Mo}\left(\mathrm{Na}_{2} \mathrm{MoO}_{4}\right)$, and $\left.1 \% \mathrm{Zn}\left(\mathrm{ZnSO}_{4}\right)\right]$. The objectives were to determine 1) if a relatively inexpensive $\left(\mathrm{FeSO}_{4}\right)$ or a relatively expensive (MM) S source best supplied S; and 2) the influence of liming PB on plant growth when fertilized with $\mathrm{FeSO}_{4}$ or Micromax. The substrate was milled PB (Pinus taeda L.). Treatments were PB preplant amended with $\mathrm{FeSO}_{4}$ at rates of $0.0,0.9,1.8$, $3.6,5.4$, or $10.8 \mathrm{~kg} \cdot \mathrm{m}^{-3}$ with or without lime; $\mathrm{PB}$ preplant amended with $\mathrm{MM}$ at rates of 0.0 , $0.9,1.8,3.6,5.4$, or $10.8 \mathrm{~kg} \cdot \mathrm{m}^{-3}$ with or without lime. For lime-amended PB treatments, ground dolomitic limestone $(18 \% \mathrm{Ca}, 10 \% \mathrm{Mg}$; James River Limestone Co., Inc., Buchanon, Va.) with a calcium carbonate equivalence of $100 \%$ was mixed into $\mathrm{PB}$ at a rate of $3.6 \mathrm{~kg} \cdot \mathrm{m}^{-3}$. Proportions of lime passing through indicated mesh size (number of holes per $2.5 \mathrm{~cm}$ ) were: size $8,100 \%$; size $10,100 \%$; size $20,90 \%$; size 50 , $55 \%$; size $60,50 \%$; and size $100,35 \%$. Plastic 15.2-L containers were filled with $\mathrm{PB}$ of the respective $\mathrm{FeSO}_{4}$ or $\mathrm{MM}$ treatment.

Twenty-five stratified Quercus palustris Münchh (Sheffield's Seed Co., Inc., Locke, N.Y.) seeds were sown (3 $\mathrm{cm}$ deep) in each PB filled container. Seeds germinated 1 to 2 weeks later and were thinned to 10 uniform seedlings per container. At each irrigation, seedlings were supplied (beaker applied) with $250 \mathrm{~mL}$ of fertilizer solution of $100 \mathrm{mg} \cdot \mathrm{L}^{-1}$ $\mathrm{N}\left(\mathrm{NH}_{4} \mathrm{NO}_{3}\right), 15 \mathrm{mg} \cdot \mathrm{L}^{-1} \mathrm{P}\left(\mathrm{H}_{3} \mathrm{PO}_{4}\right)$, and 50 $\mathrm{mg} \cdot \mathrm{L}^{-1} \mathrm{~K}(\mathrm{KCl})$. Other greenhouse culture and conditions were the same as the previously mentioned experiments. Treatments commenced on 25 Apr. 2003, and terminated on 11 Sept. 2003. Pine bark solutions were extracted on 3 Aug. 2003 from containers using the PT method and analyzed as described above for pH, S, Cu, Fe, Mn, and Zn. On 11 Sept. 2003, plant shoots were severed at the soil surface, dried for about $6 \mathrm{~d}$ at $65^{\circ} \mathrm{C}$, and dry weights were recorded.

The experimental design for the pin oak$\mathrm{K}_{2} \mathrm{SO}_{4}$ experiment and japanese maple $-\mathrm{K}_{2} \mathrm{SO}_{4}$ experiment was completely randomized with six single container replications per treatment and three subsamples per container. The experimental design for the Micromax--FeSO - -lime experiment was completely randomized with four single container replications per treatment and ten subsamples per container. All data were analyzed by A.O.V. using SAS (version 8.02) PROC GLM and subjected to regression analysis using SigmaPlot (version 8.02 SPSS, Inc., Chicago, Ill.).

\section{Results and Discussion}

Pinoak- $\mathrm{K}_{2} \mathrm{SO}_{4}$ andjapanese maple- $\mathrm{K}_{2} \mathrm{SO}_{4}$ experiments. Regression analysis revealed that maximum growth of pin oak and japanese maple occurred at an application concentration of about $30 \mathrm{mg} \cdot \mathrm{L}^{-1} \mathrm{~S}$ and higher (Fig. $1 \mathrm{~A}$ and B). At $30 \mathrm{mg} \cdot \mathrm{L}^{-1} \mathrm{~S}$, the corresponding substrate solution concentrations were 15 and $7 \mathrm{mg} \cdot \mathrm{L}^{-1}$ $\mathrm{S}$ for oak and maple, respectively (Fig. 2A and B). These concentrations are within sufficiency ranges reported earlier for a number of species. Shoot tissue $\mathrm{S}$ concentrations for the $40 \mathrm{mg} \cdot \mathrm{L}^{-1} \mathrm{~S}$ treatment (treatment closest to maximum growth) were $0.16 \%$ and $0.26 \%$ for oak and maple, respectively (Table 1 ). These shoot tissue concentrations are comparable to the $\mathrm{S}$ leaf tissue concentrations found in pin oak $(0.16 \%$ to $0.19 \%)$ and japanese maple $(0.19 \%$ to $0.30 \%)$ (Mills and Jones, 1996$)$. Substrate solution $\mathrm{pH}$ values for all treatments for both pin oak and japanese maple were in the ranges of 5.1 to 5.5 and were unaffected by treatment $(P \leq 0.05)$.

Micromax-FeSO-lime experiment. Highest dry weight values for pin oak occurred at the $0.9 \mathrm{~kg} \cdot \mathrm{m}^{-3} \mathrm{MM}$ and $\mathrm{FeSO}_{4}$ rates and higher for unlimed PB treatments (Fig. 3), which provided 3.0 and $3.4 \mathrm{mg} \cdot \mathrm{L}^{-1} \mathrm{~S}$ in substrate solution, respectively (Table 2 ). These concentrations are lower than those associated with maximum growth with the two previous experiments; however, they are comparable to the recommended substrate solution concentration for peach (Prunus persica L. Batsch) in sand culture (Finch et al., 1997), and are at least three times greater than the substrate solution concentrations of the limed treatments at the

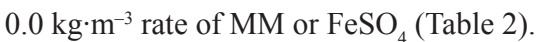

For the unlimed treatments, there was an abrupt increase in dry weight in response to the increasing rates of $\mathrm{MM}$ and $\mathrm{FeSO}_{4}$ (Fig. $3)$. In contrast, the dry weight increase for limed treatments was gradual in response to the increasing rate of MM in limed PB (Fig. $3)$. For the unlimed treatments, the increase in dry weights from the 0.0 rate to the rate at which maximum growth occurred was $161 \%$ and $167 \%$ for the $\mathrm{FeSO}_{4}$ and MM treatments, respectively. For the limed treatments, the increase in dry weights from the 0.0 rate to the rate at which maximum growth occurred was $54 \%$ and $80 \%$ for the $\mathrm{FeSO}_{4}$ and MM treatments, respectively. These data are

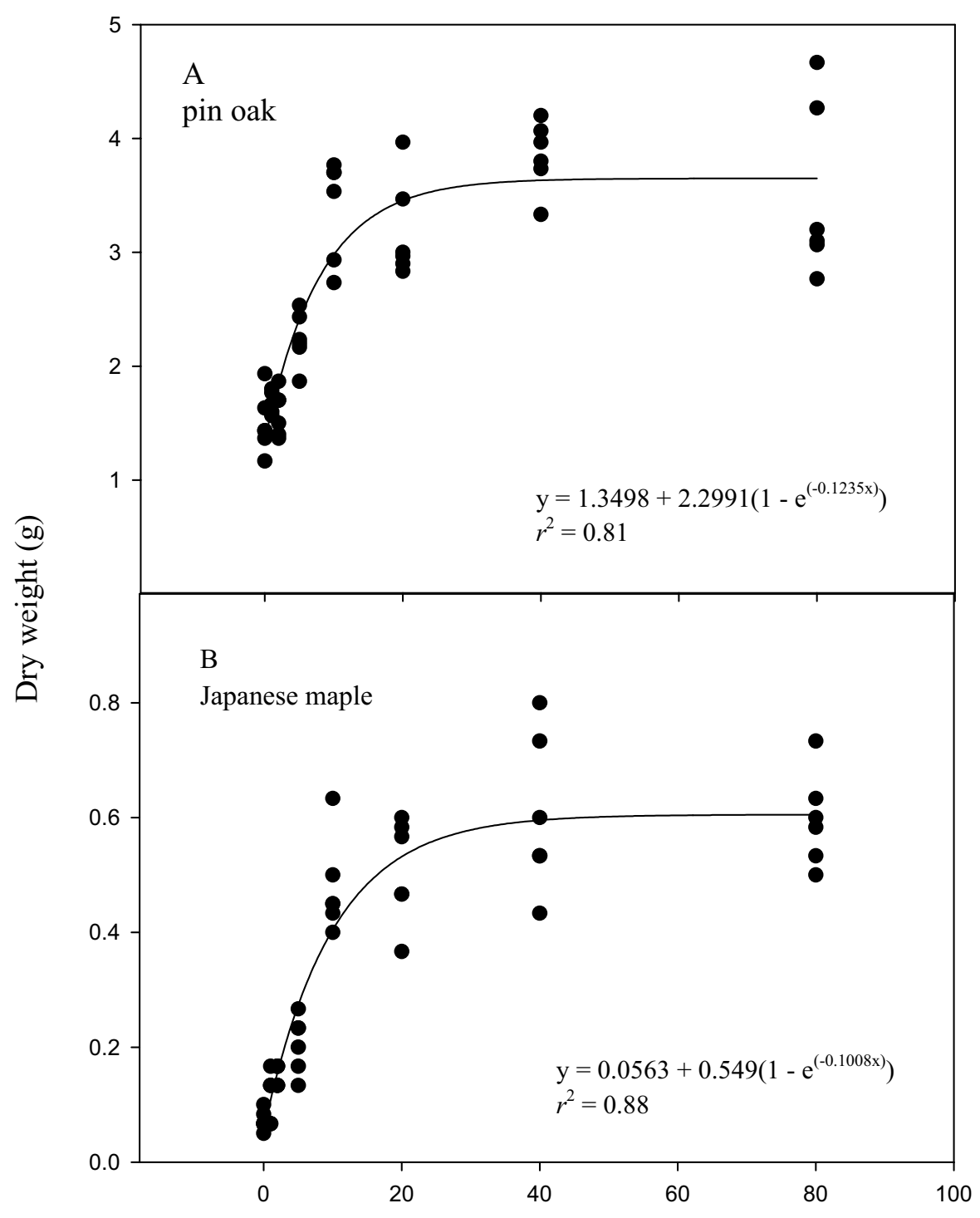

\section{S application rate $\left(\mathrm{mg}^{-1 \text { liter }}{ }^{-1}\right)$}

Fig. 1. Influence of S application rate on mean shoot dry weight of container-grown (A) japanese maple and (B) pin oak seedlings. Means are results of three subsamples per container $(\mathrm{n}=6)(P \leq 0.0001)$. 
consistent with the findings of Wright et al. (1999a, 1999b) who observed that amending PB with lime reduced growth of nine container-grown tree species in a PB substrate. This growth reduction was attributed to reduced micronutrient availability at higher substrate $\mathrm{pH}$. In the current work, substrate solution micronutrient concentrations for limed MM ( $\mathrm{pH}$ 6.1) and limed $\mathrm{FeSO}_{4}(\mathrm{pH}$ 5.6 to 6.1 ) treatments were generally lower than unlimed treatments $(\mathrm{pH} \leq 4.5)$ (Table 2). Plant response to the MM treatment was

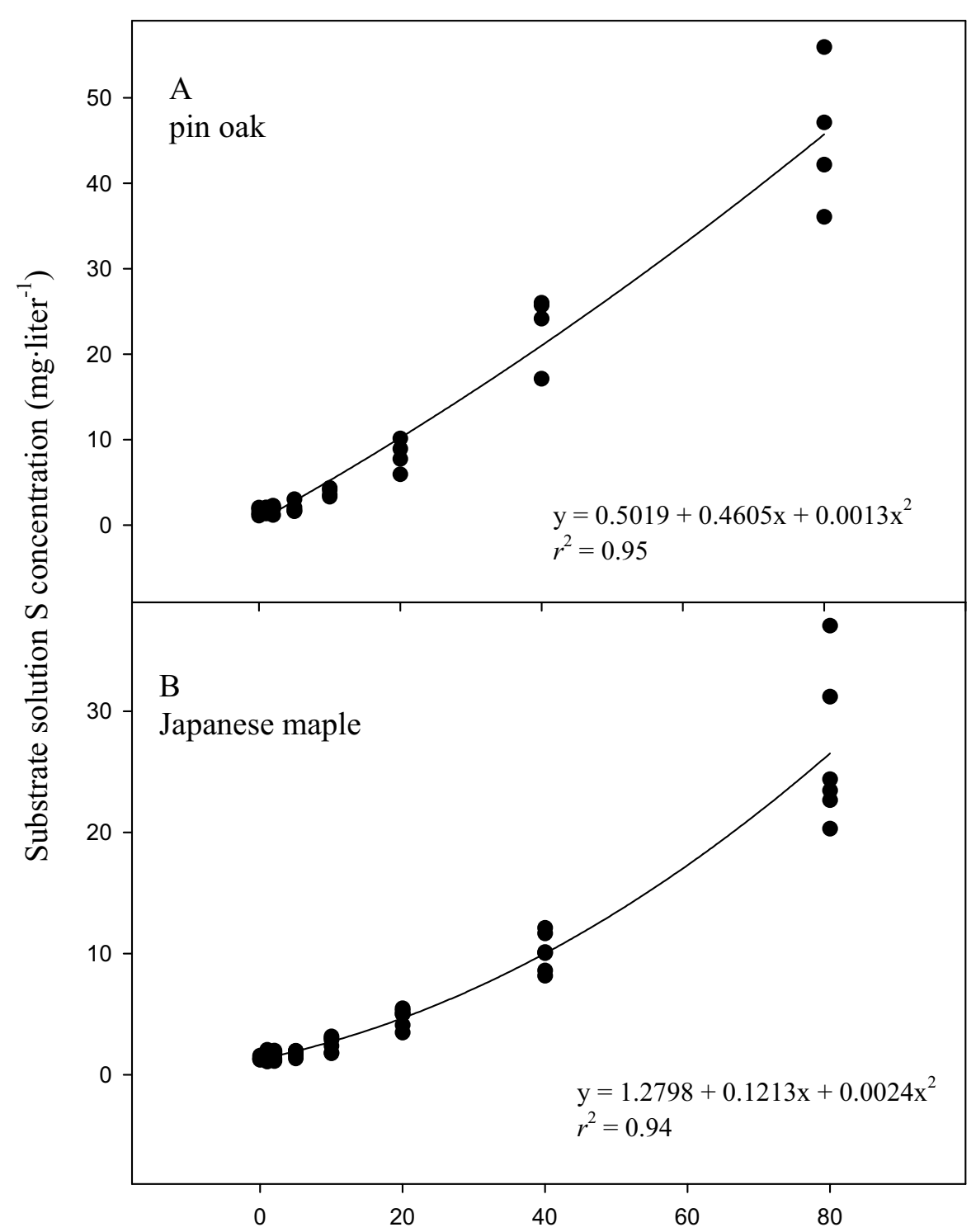

$\mathrm{S}$ application rate $\left(\mathrm{mg} \cdot\right.$ liter $\left.^{-1}\right)$ greater than the $\mathrm{FeSO}_{4}$ treatment in a limed substrate most likely because MM supplies $\mathrm{Cu}, \mathrm{Fe}, \mathrm{Mn}$, and $\mathrm{Zn}$ as well as $\mathrm{S}$. The $\mathrm{FeSO}_{4}$ treatment only supplied $\mathrm{Fe}$ and $\mathrm{S}$, and the lesser amount of growth was apparently due to micronutrient deficiencies. In situations where micronutrient supply is relatively low in a PB substrate, such as high $\mathrm{pH}$ (6.1), MM addition is suggested at a rate of $5.4 \mathrm{~kg} \cdot \mathrm{m}^{-3}$ since it supplies adequate $\mathrm{S}$ and micronutrients. The effect of adding lime to a substrate would be similar to growers whose water is less pure than used in this study since dolomitic lime addition increases substrate solution $\mathrm{Ca}$, $\mathrm{Mg}$, and bicarbonate concentrations. Thus, plants irrigated with alkaline water would most likely respond to micronutrients in a sulfated micronutrient fertilizer as plants in the lime treatment of this study. In situations where the $\mathrm{pH}$ of a $\mathrm{PB}$ substrate is relatively low (4.5), then $\mathrm{FeSO}_{4}$ addition is suggested at a rate of $0.9 \mathrm{~kg} \cdot \mathrm{m}^{-3}$ instead of $\mathrm{MM}$, since the micronutrients (supplied by $\mathrm{PB}$ ) in a low $\mathrm{pH} \mathrm{PB}$ will be in an available form. In terms of fertilizer costs, $\mathrm{FeSO}_{4}$ is significantly less expensive than MM.

Under conditions of these experiments, regression analysis showed that a $30 \mathrm{mg} \cdot \mathrm{L}^{-1}$ $\mathrm{S}$ fertilizer solution (in addition to other elements) resulted in maximum growth of pin oak and japanese maple when fertilizer was applied to maintain a substrate solution EC of 1.0 to $1.5 \mathrm{dS} \cdot \mathrm{m}^{-1}$. Other conditions, such as the amount of $\mathrm{SO}_{2}$ in the atmosphere, the frequency and amount of irrigation and fertilizer application, and whether there are sufficient $S$ concentrations inherent in the $\mathrm{PB}$ will affect the substrate solution $\mathrm{S}$ concentration. Other work (unpublished data) for container-grown pin oak showed that PB source influenced growth response to $\mathrm{S}$ fertilization. Sulfur fertilization was required to increase plant dry weight values over the control treatment in $\mathrm{PB}$ which supplied $1 \mathrm{mg} \cdot \mathrm{L}^{-1} \mathrm{~S}$ in the substrate solution, however $\mathrm{S}$ addition was not required to increase dry weights over control when grown in $\mathrm{PB}$ which supplied $12 \mathrm{mg} \cdot \mathrm{L}^{-1} \mathrm{~S}$ in the substrate solution. Elemental analysis of plant tissue grown in these PB types revealed that the former was deficient in $\mathrm{S}$ and the latter was not. These data indicated that the source of PB used to grow nursery crops could greatly influence substrate solution $\mathrm{S}$ concentrations.
Fig. 2. Influence of $\mathrm{S}$ application rate on mean substrate solution $\mathrm{S}$ concentration for containergrown (A) japanese maple and (B) pin oak seedlings. Means are results of three subsamples per container $(\mathrm{n}=6)(P \leq 0.0001)$.
Table 1. Concentrations of elements found in dry weight leaf tissue samples of container-grown pin oak (pin oak- $\mathrm{K}_{2} \mathrm{SO}_{4}$ ) and japanese maple (japanese maple- $\mathrm{K}_{2} \mathrm{SO}_{4}$ ) seedlings as affected by $\mathrm{S}$ application concentration. Means are results of three subsamples per container.

\begin{tabular}{lccccc}
\hline & $\mathrm{S}$ & $\mathrm{Cu}$ & $\mathrm{Fe}$ & $\mathrm{Mn}$ & $\mathrm{Zn}$ \\
\cline { 3 - 6 } Treatment & $(\%)$ & \multicolumn{3}{c}{$\left(\mathrm{mg} \cdot \mathrm{kg}^{-1}\right)$} \\
\hline Pin oak & & & & \\
$0 \mathrm{mg} \cdot \mathrm{L}^{-1} \mathrm{~S}$ & $0.08 \mathrm{~b}^{2}$ & $3.5 \mathrm{a}$ & $63.0 \mathrm{a}$ & $1050 \mathrm{a}$ & $54.0 \mathrm{a}$ \\
$40 \mathrm{mg} \cdot \mathrm{L}^{-1} \mathrm{~S}$ & $0.16 \mathrm{a}$ & $2.5 \mathrm{a}$ & $69.5 \mathrm{a}$ & $567 \mathrm{~b}$ & $52.0 \mathrm{a}$ \\
Japanese maple & & & & & \\
$0 \mathrm{mg} \cdot \mathrm{L}^{-1} \mathrm{~S}$ & $0.08 \mathrm{~b}$ & $5.0 \mathrm{a}$ & $80 \mathrm{a}$ & $465 \mathrm{a}$ & $48.5 \mathrm{a}$ \\
$40 \mathrm{mg} \cdot \mathrm{L}^{-1} \mathrm{~S}$ & $0.26 \mathrm{a}$ & $3.5 \mathrm{a}$ & $77 \mathrm{a}$ & $346 \mathrm{a}$ & $55.5 \mathrm{a}$ \\
\hline
\end{tabular}

${ }^{2}$ Means separation in columns by Duncan's multiple range test, $P \leq 0.05(\mathrm{n}=4)$. Treatments within columns with the same letters are not significantly different. 


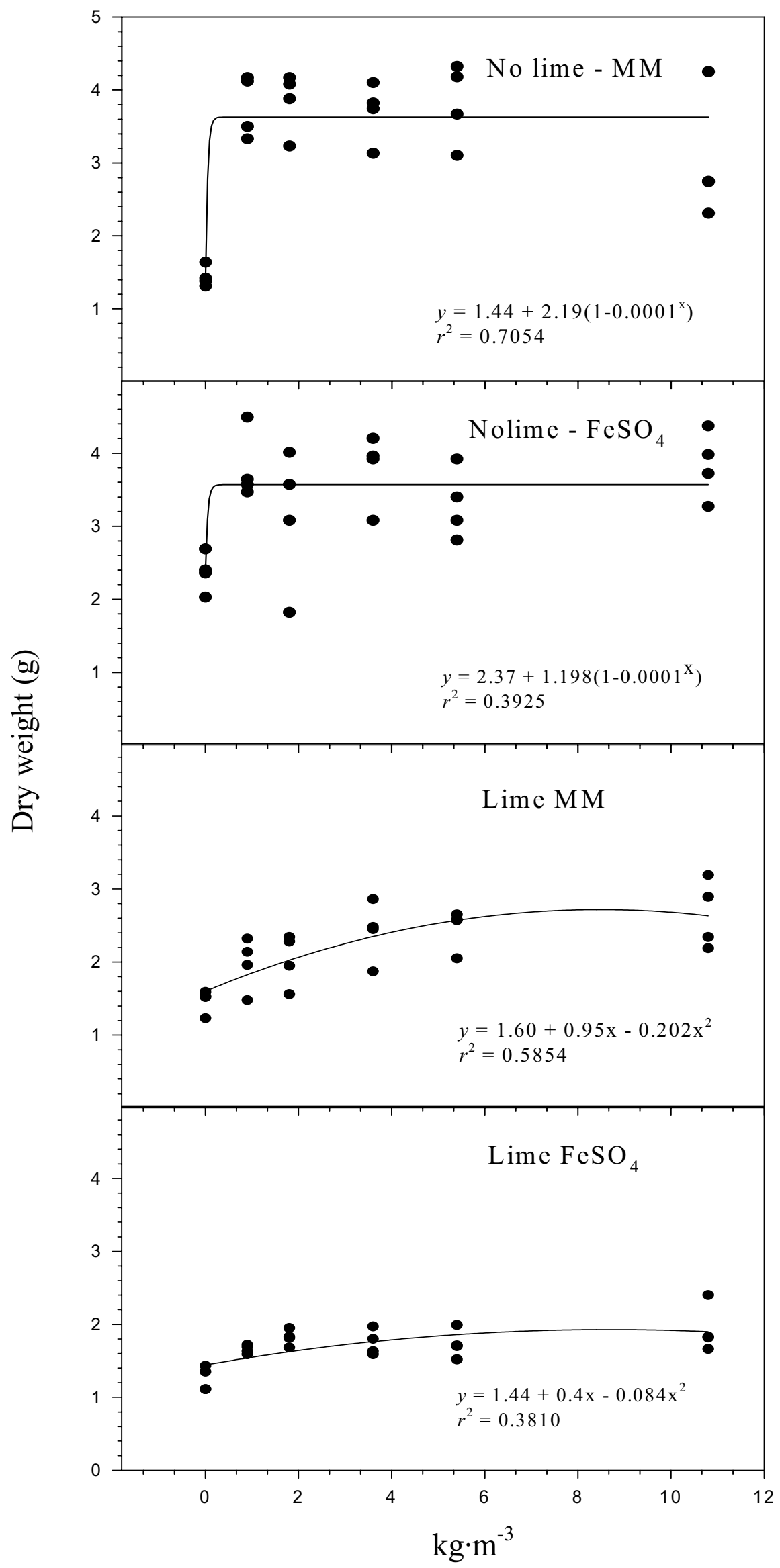

Fig. 3. Influence of $\mathrm{FeSO}_{4}$ and Micromax (limed and unlimed substrates) on mean shoot dry weight of container-grown pin oak seedlings. Means are results of 10 subsamples per container $(\mathrm{n}=4)(P \leq$ $0.0001)$. 
Table 2. Substrate solution $\mathrm{pH}$ and nutrient concentrations sampled on 3 Aug. 2003, 14 weeks after treatment commencement for container-grown pin oak seedlings (Micromax, $\mathrm{FeSO}_{4}$, lime) as affected by Micromax or $\mathrm{FeSO}_{4}$ (limed or unlimed) treatments. Means are results of 10 subsamples per container.

\begin{tabular}{|c|c|c|c|c|c|c|}
\hline \multirow[b]{2}{*}{ Rate } & \multirow[b]{2}{*}{$\mathrm{pH}$} & \multicolumn{5}{|c|}{ Nutrient $\left(\mathrm{mg} \cdot \mathrm{L}^{-1}\right)$} \\
\hline & & $\mathrm{S}$ & $\mathrm{Cu}$ & $\mathrm{Fe}$ & $\mathrm{Mn}$ & $\mathrm{Zn}$ \\
\hline \multicolumn{7}{|c|}{ Micromax (unlimed) } \\
\hline 0 & 4.5 & 0.7 & 0.004 & 0.20 & 0.068 & 0.032 \\
\hline 0.9 & 4.3 & 3.0 & 0.009 & 0.28 & 0.045 & 0.047 \\
\hline 1.8 & 4.2 & 11.2 & 0.007 & 0.47 & 0.056 & 0.071 \\
\hline 3.6 & 4.0 & 26.8 & 0.015 & 0.34 & 0.162 & 0.124 \\
\hline 5.4 & 3.8 & 72.2 & 0.021 & 0.38 & 0.406 & 0.363 \\
\hline \multirow[t]{2}{*}{10.8} & 3.7 & 199.9 & 0.046 & 0.42 & 3.204 & 1.678 \\
\hline & $* * *$ & $* * *$ & $* * *$ & NS & $* * *$ & $* * *$ \\
\hline \multicolumn{7}{|c|}{$\mathrm{FeSO}_{4}$ (unlimed) } \\
\hline $0^{4}$ & 4.1 & 1.1 & 0.007 & 0.27 & 0.061 & 0.042 \\
\hline 0.9 & 4.1 & 3.4 & 0.007 & 0.21 & 0.050 & 0.052 \\
\hline 1.8 & 4.1 & 11.0 & 0.007 & 0.33 & 0.103 & 0.053 \\
\hline 3.6 & 3.8 & 36.4 & 0.006 & 0.30 & 0.083 & 0.060 \\
\hline 5.4 & 3.7 & 86.8 & 0.008 & 0.40 & 0.380 & 0.138 \\
\hline \multirow[t]{2}{*}{10.8} & 3.5 & 144.6 & 0.007 & 0.61 & 0.421 & 0.192 \\
\hline & $* * *$ & $* * *$ & $* * *$ & $* * *$ & NS & $*$ \\
\hline \multicolumn{7}{|c|}{ Micromax (limed) } \\
\hline 0 & 6.1 & 1.1 & $--^{z}$ & 0.07 & 0.004 & 0.033 \\
\hline 0.9 & 6.0 & 1.7 & --- & 0.09 & 0.013 & 0.024 \\
\hline 1.8 & 6.0 & 4.8 & 0.003 & 0.14 & 0.011 & 0.031 \\
\hline 3.6 & 5.8 & 15.9 & 0.002 & 0.13 & 0.018 & 0.041 \\
\hline 5.4 & 5.6 & 66.2 & 0.001 & 0.17 & 0.019 & 0.054 \\
\hline \multirow[t]{2}{*}{10.8} & 5.6 & 73.3 & 0.021 & 0.15 & 0.074 & 0.105 \\
\hline & $* * *$ & $* * *$ & $* * *$ & $* *$ & $* * *$ & $* * *$ \\
\hline \multicolumn{7}{|c|}{$\mathrm{FeSO}_{4}$ (limed) } \\
\hline $0^{4}$ & 6.1 & 0.8 & 0.004 & 0.05 & 0.008 & 0.019 \\
\hline 0.9 & 5.9 & 1.4 & 0.006 & 0.15 & 0.011 & 0.025 \\
\hline 1.8 & 6.1 & 4.0 & 0.006 & 0.11 & 0.007 & 0.020 \\
\hline 3.6 & 5.9 & 18.5 & 0.006 & 0.44 & 0.012 & 0.022 \\
\hline 5.4 & 6.0 & 18.8 & 0.007 & 0.19 & 0.026 & 0.020 \\
\hline \multirow[t]{2}{*}{10.8} & 5.7 & 57.8 & 0.004 & 0.21 & 0.028 & 0.023 \\
\hline & $*$ & $* * *$ & $* * *$ & NS & $* *$ & NS \\
\hline
\end{tabular}

${ }^{\mathrm{z}}$ Sample concentration below detectable level of instrument.

NS, ${ }^{* * * * * * * *}$ Nonsignificant or significant at $P<0.05,0.01$, or 0.001 , respectively.

\section{Literature Cited}

Bixby, D.W. and J.D. Beaton. 1970. Sulphur containing fertilizers properties and applications. The Sulphur Inst. Bul. 17.

Browder, J.F. 2004. Sulfur requirements of containergrown pin oak and Japanese maple. MS thesis. Va. Polytechnic Inst. State Univ., Blacksburg.

Dale, M.E., E.T. Paparozzi, and J.D. Carr. 1990. Sulfur deficiency in poinsettia. HortScience 25:424-426.

Finch, C.R., D.H. Byrne, C.G. Lyons, and H.D. Pennington. 1997. Sulfur nutrition requirements of peach trees. J. Plant Nutr. 20:1711-1721.

Handreck, K.A. 1986. Critical concentrations of sulfur in liquid feeds for plants in containers. Scientia Hort. 30:1-17.

Hu, H., D. Sparks, and J.J. Evans. 1991. Sulfur deficiency influences vegetative growth, chlorophyll and element concentrations, and amino acids of pecan. J. Amer. Soc. Hort. Sci. 116:974-980.

Huang, L., E.T. Paparozzi, and C. Gotway. 1997. The effect of altering nitrogen and sulfur supply on the growth of cut chrysanthemums. J. Amer. Soc. Hort. Sci. 122:559-564.

Karmoker, J.L., D.L. Clarkson, L.R. Saker, J.M. Rooney, and J.V. Purves. 1991. Sulphate deprivation depresses the transport of nitrogen to the xylem and the hydraulic conductivity of barley (Hordeum vulgare L.) roots. Planta 1985:269-278.

Kastori, R., M. Plesnicar, I. Arsenijevic-Maksimovic, N. Petrovic, D. Pankovic, and Z. Sakac. 2000. Photosynthesis, chlorophyll fluorescence, and water relations in young sugar beet plants as affected by sulfur supply. J. Plant Nutr. 23:1037-1049.
Leustek, T., M.N. Martin, J. Bick, and J.P. Davies. 2000. Pathways and regulation of sulfur metabolism revealed through molecular and genetic studies. Annu. Rev. Plant Physiol. Plant Mol. Biol. 51:141-165.

Macz, O., E.T. Papparozzi, W.W. Stroup, R. Leonard, and T.A. Nell. 2001. Effect of nitrogen and sulfur applications on pot chrysanthemum production and postharvest performance. J. Plant Nutr. 24:131-146.

Mengel, K. and E.A. Kirkby. 2001. Principles of plant nutrition. 5th ed. Kluwer Academic Publ., London.

Mills, H.A. and J.B. Jones, Jr. 1996. Plant analysis handbook II. Micromacro Publ., Inc., Athens, Ga.

National Atmospheric Deposition Program.2004. NRSP-3. NADP Program Office, Ill. State Water Survey, Champaign.

Nelson, P.V. 1996. Macronutrient fertilizer programs, p. 141-170. In: D.W. Reed(ed.).Agrowers guide to water, media, and nutrition for greenhouse crops. Ball Publ., Batavia, Ill.

Yeager, T.H., R.D. Wright, and S.J. Donohue. 1983. Comparison of pour-through and saturated pine bark extract N, P, K, and pH levels. J. Amer. Soc. Hort. Sci. 108:112-114.

Wright, A.N., A.X. Niemiera, J.R. Harris, and R.D. Wright. 1999a. Micronutrient fertilization of woody seedlings essential regardless of pine bark pH. J. Environ. Hort. 17:69-72.

Wright, A.N., A.X. Niemiera, J.R. Harris, and R.D. Wright. 1999b. Preplant lime and micronutrient amendments to pine bark affect growth of seedlings of nine container-grown tree species. HortScience 34:669-673. 